\title{
Synthesis of Cyclohexene Derivatives from 1,5-Enynes via Gold- Catalysis and Iodocyclization: A Comparative Study and Applications in the Synthesis of 7/5- or 8/5-Fused Rings and Biaryls ${ }^{\dagger}$
}

\author{
Youngun Lee, Choongmin Lim, Sunghwan Kim, ${ }^{\star}$ and Seunghoon Shin* \\ Department of Chemistry and Institute for Natural Sciences, Hanyang University, Seoul 133-791, Korea \\ *E-mail:sshin@hanyang.ac.kr \\ *Department of Chemistry, Kyungpook National University, Daegu 702-701, Korea \\ Received December 12, 2009, Accepted December 23, 2009
}

\begin{abstract}
A comparative study on the $\mathrm{Au}(\mathrm{I})$-catalyzed and IBr-promoted tandem cyclization of 1,5-enyne was reported. This study provides a meaningful mechanistic insight to the concerted nature of this tandem reaction and also provides interesting applications in the synthesis of 7/5- or 8/5-fused bicycles and biaryls.
\end{abstract}

Key Words: Gold catalysis, Iodocyclization, Tandem reaction, 1,5-Enyne, Carbocycles

\section{Introduction}

Tandem reactions are highly efficient means of enhancing synthetic efficiency in the synthesis of complex molecules. ${ }^{1}$ Recent explosive developments in homogeneous gold catalysis is due to the ability of $\mathrm{Au}(\mathrm{I})$ or $\mathrm{Au}(\mathrm{III})$-species to activate unsaturated $\pi$-bonds, where gold generates formal carbocationic intermediates and catalyze various tandem cyclizations. ${ }^{2}$ We and others have recently reported $\mathrm{Au}(\mathrm{I})$-catalyzed tandem cyclization, terminating with $t$-Boc trapping, ${ }^{3}$ where the cationic vinyl gold species $\mathbf{A}$ is proposed to be stabilized by back-bonding interaction of gold as in $\mathbf{A}^{\prime}$. On the other hand, this stereochemical outcome can be emulated by iodine-induced cyclization of 1,5enyne, where the metal back-bonding interaction is absent. ${ }^{4}$ In the latter case, a concerted $\mathrm{C}-\mathrm{C}$ and $\mathrm{C}-\mathrm{O}$ bond formation can be invoked to rationalize the stereochemical outcome. However, in some cases, liberated bromide acts as a competing nucleophile, which stands contradictory to the concerted pathway (Scheme 1). Therefore, a comparative study on the Au-catalyzed cyclization and iodocyclization would give a meaningful insight as to tandem 1,5-enyne cyclization mechanism. In addition, we report

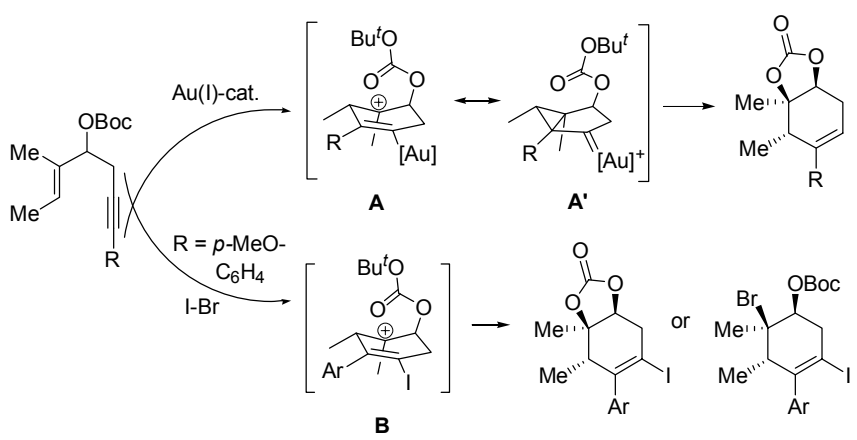

Scheme 1. Au(I)-catalyzed and iodonium-promoted tandem cyclization of 1,5-enyne

${ }^{\dagger}$ This paper is dedicated to Professor Sunggak Kim on the occasion of his honorable retirement. herein two synthetic manipulations of the resulting cyclohexene derivatives that are potentially useful in the synthesis of natural products as well as biaryl ligands.

To expand the synthetic utility and also to provide a mechanistic insight as to the tandem cyclization, we prepared substrates having $t$-BocO trap elsewhere in the molecule rather than at $\mathrm{C} 3$ of 1,5-enyne. The synthesis of these substrates is depicted in Scheme 2. For example, the synthesis of substrate $\mathbf{2}$ started from a known aldehyde derived from geraniol, ${ }^{5 a}$ which was homologated by Bestmann reagent into the 1,5-enyne. Subsequent Sonogashira coupling followed by attaching $t$-Boc group on the resulting alcohol provided 2 . Treating 2-(trimethylsilylmethyl) prop-2-ene-1-ol 3 with $n$-BuLi induced silyl group transfer to form an allyl lithium species, ${ }^{5 b}$ which was reacted with a propargyl bromide derivative to form 4 . A similar sequence starting from aldehyde 5 led to a secondary alcohol $\mathbf{6}$ that was then converted into the carbonate 7 . We also planned to explore 1,5-enyne cyclization trapped with a carboxylic acid. For this purpose, 1,5-enyne alcohol 1 was first converted into the $\gamma, \delta$-unsaturated acid $\mathbf{8}$, which subsequently was alkylated and/or hydrolyzed to provide substrates $\mathbf{9}$ or $\mathbf{1 0}$.

With these 1,5-enyne substrates in hand, we explored goldcatalyzed and iodonium-induced cyclizations. Previously, we have shown that the alkyne substituent has strong impact on the course of iodocyclization of 1,5-enyne. 1,5-Enynes having alkyne substituents such as $\mathrm{H}$, TMS, $\mathrm{Br}, o-\mathrm{NO}_{2} \mathrm{C}_{6} \mathrm{H}_{4}$, and Me, induces monocyclization with alkene to form $\mathrm{C}-\mathrm{I}$ and $\mathrm{C}-\mathrm{O}$ bonds, while phenyl or electron-rich aryl ring at alkyne induces tandem cyclization with both alkene and alkyne, where C-I, C-C and $\mathrm{C}-\mathrm{O}$ bonds form simultaneously. ${ }^{4 \mathrm{a}}$ Therefore, all substrates in this comparitive study utilized aryl substituted alkynes. In Au(I)catalyzed reaction, substrates $\mathbf{2}$ and $\mathbf{4}$ with a primary $O$-Boc group and the carboxylic acid 9' (Ph derivative of 9) underwent a smooth tandem cyclization into the respective carbonates or lactones, 11, 12, and 13. Electron-density on the aryl substituted alkyne did not affect the course of the cyclization and both 14 and 16 reacted with more or less similar efficiency and diastereoselectivity (entries 4 and 5). 


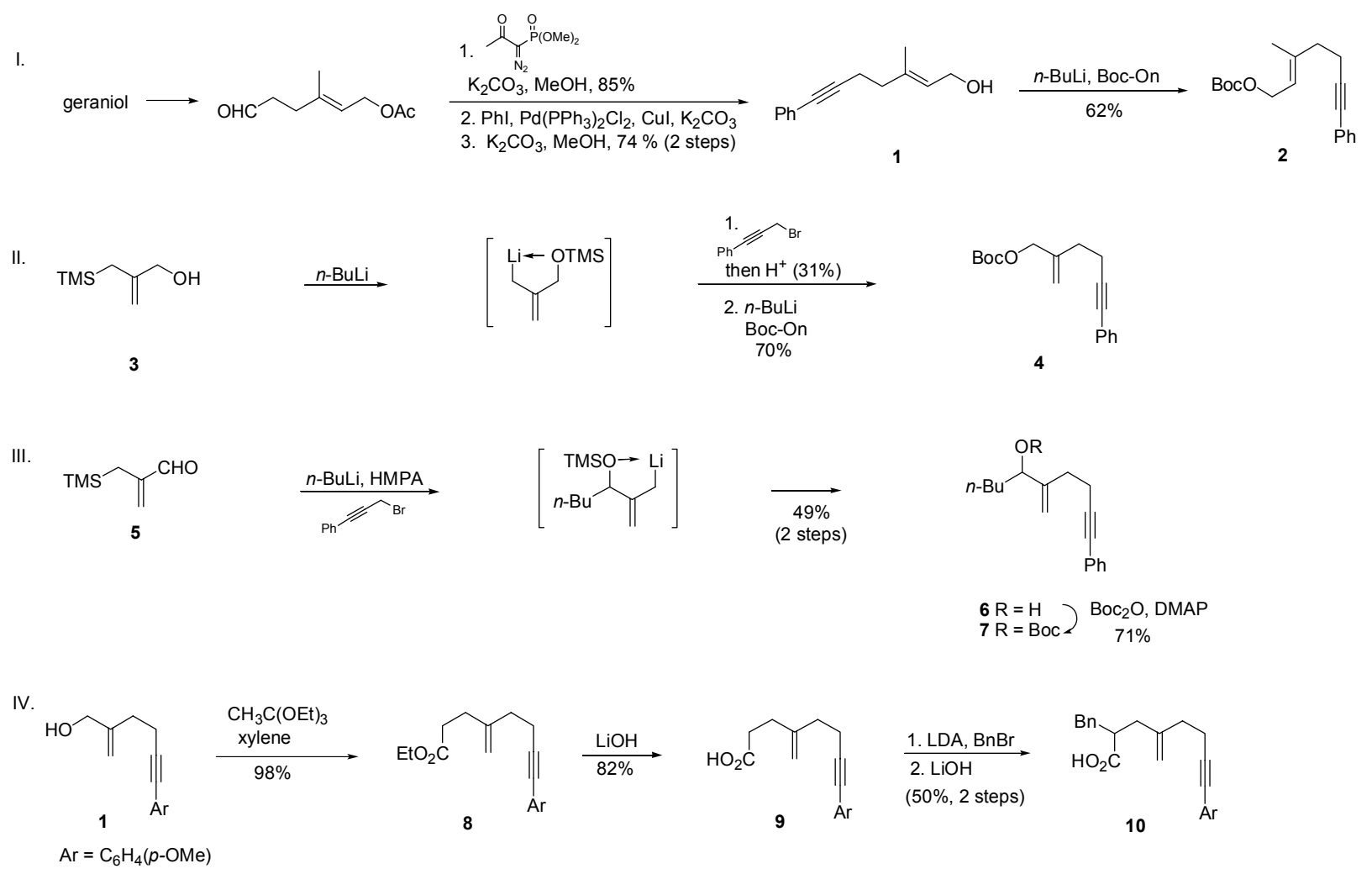

Scheme 2. Synthesis of substrates 2, 4, 7, 9, and $\mathbf{1 0}$

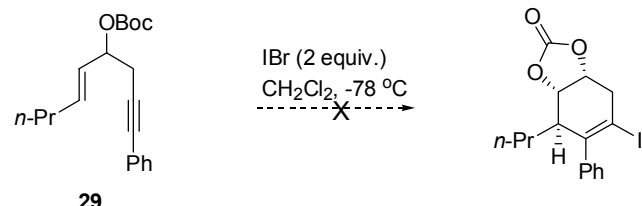

Scheme 3. Failed cyclization of substrate 29

In contrast, IBr-promoted reaction of substrate 2 and $\mathbf{4}$ led to a mixture of products arising from $O$-Boc trapping (20 and 22) as well as bromide trapping ( 21 and $\mathbf{2 3}$ ) in about 1:2 ratio (entries 7 and 8). IBr-promoted cyclization of 9 led to a low yield of desired product from a messy reaction (not shown). Therefore, $\alpha-$ substituted 10, aided by Thorp-Ingold effect, was expected to result in a more efficient cation-trapping by carboxylic acid. As expected, the cyclization of $\mathbf{1 0}$ led to isolation of the product 24 in 56\% yield and none of the iodobromination product was observed in the reaction mixture. Similarly, secondary $O$-Boc group also efficiently trapped the forming carbocation and $\mathbf{2 5}$ was obtained as a sole product in $64 \%$ yield. A competing iodobromination product can also be observed in the reaction of 14. While $\mathrm{Au}(\mathrm{I})$-catalyzed cyclization led to a smooth formation of 15, IBr-promoted cyclization led to a mixture of $\mathbf{2 6}$ and 27 (entries 4 and 11). Interestingly, when there is less electron-density on the aryl ring, the formation of iodobromination product is minimized (entry 12). Also in this iodocyclization, presence of cation-stabilizing substituent at the olefin in the starting substrate was crucial for the successful cyclization. For example, substrate 29 (Scheme 3) failed to cyclize under the standard condition.

The above results in Table 1 shows a surprisingly high diastereoselectivity that could not be fully answered only on the basis of stereoelectronic arguments. We interpreted these results on the basis of the mechanistic model shown in Scheme 4. It is well known that coordination of aryl-substituted alkyne with iodonium reagents results in formation of the open vinyl cation D that has linear coordination geometry. ${ }^{6}$ The stability of this open vinyl cation $\mathbf{D}$ relative to the cyclic complex $\mathbf{C}$ correlates well with the electron-donating ability of alkynyl substituent, both computationally and experimentally. Thus the presence of $\mathrm{C}_{6} \mathrm{H}_{4}(p-\mathrm{OMe})$ at Ar position (entry 11, Table 1$)$ seem to increase the lifetime of $\mathbf{D}$, and a fully dissociated bromide ion develops in the mixture and competes with the intramolecular carbonate as a cation-trapping nucleophile. This is also true when the intra-
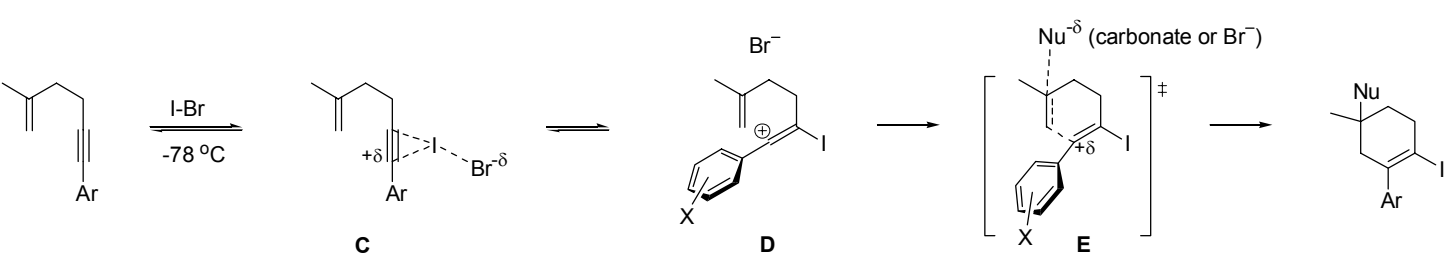

Scheme 4. Mechanistic model for the iodocyclization 
Table 1. Gold-catalyzed and iodonium-promoted cyclization of 1,5-enyne

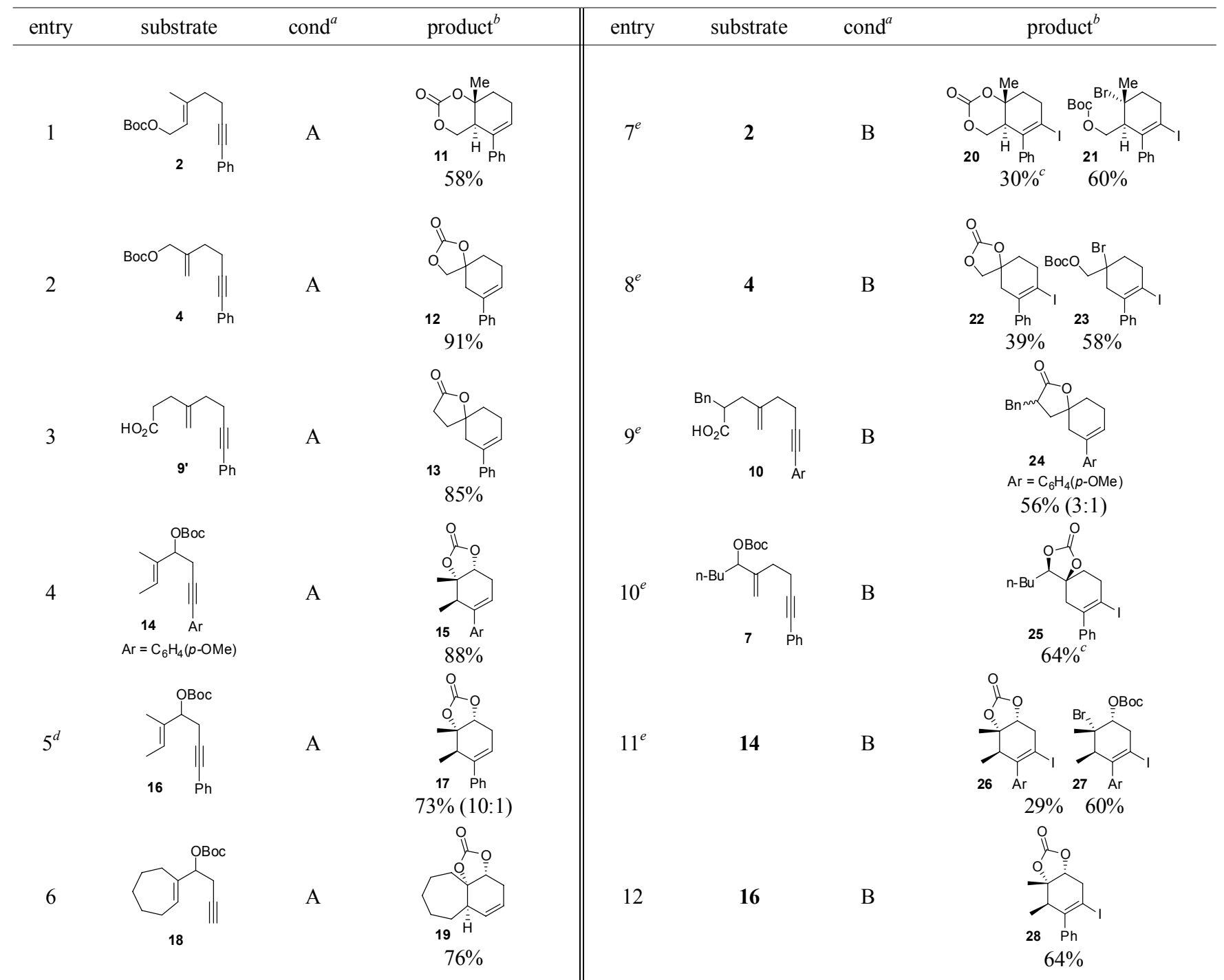

${ }^{a}$ Condition $\mathrm{A}: \mathrm{Au}\left[t-\mathrm{Bu}{ }_{2} \mathrm{P}(o\right.$-biphenyl) $] \mathrm{SbF}_{6}(2 \mathrm{~mol} \%)$ in $\mathrm{DCE}$ at rt; Condition $\mathrm{B}: \mathrm{IBr}(2.0$ equiv. $)$ in $\mathrm{CH}_{2} \mathrm{Cl}_{2}$ at $-78{ }^{\circ} \mathrm{C} .{ }^{b}$ Isolated yield after chromatography; A single diastereomer unless diastereomeric ratio was noted in parenthesis. ${ }^{c} \mathrm{NOE}$ experiments supports this stereochemical assignment. ${ }^{d}$ ref. $3 \mathrm{a} .{ }^{e}$ ref. $4 \mathrm{a}$.

molecular $t$-Boc carbonate is placed at the less effective position for nuclepophilic trapping (entries 7 and 8). The following concerted transition state (E) for the $\mathrm{C}-\mathrm{C}$ and $\mathrm{C}-\mathrm{Br}$ bond formations explains the high diastereoselectivity observed. On the other hand, when the Ar group is less donating (such as with $\mathrm{Ph}$ ) or when the more effective intramolecular nucleophilic attack becomes feasible (entries 9, 10 and 12, Table 1), the open vinyl cation $\mathbf{C}$ is less fully developed and the nucleophilic attack seems to be concerted with the vinyl cation formation as well as nucleophilic trapping.

We next examined the synthetic utility of the cyclohexene products obtained in the gold-catalyzed and iodonium-promoted tandem cyclization (Scheme 5). 7,5-Fused carbocycles are abundantly found in guainane family of natural products and we inspected the ring expansion of our cyclohexane-1,2-diol derivatives 30. ${ }^{3 a}$ First, the carbonate $\mathbf{3 0}$ was deprotected with base, and was treated with methanesulfonyl chloride to get $\mathbf{3 2}$ which was selectively mesylated on the secondary alcohol. We examined a variety of conditions for the proposed ring expansion chemistry. However, after extensive trials, we failed to get the desired 7,5-fused ring and instead we obtained tetrahydronaphthalene as a major side reaction product. Having noted the presence of endocyclic double bond led to a facilitation of the undesired elimination, we then converted the olefin into a diol 33 via osmium catalyzed dihydroxylation. Protection of newly formed secondary 1,2-diol, followed by hydrolysis of carbonate and mesylation of the resulting alcohol led to 34 in $85 \%$ yield (over 3 steps). After some screening of reaction conditions (base, solvent and temperature), we found that treatment of 34 with potassium $t$-butoxide at room temperature led to a clean formation of the desired 7,5-trans-fused carbocycle $\mathbf{3 5}$ in gratifying 79\% yield. A selective formation of 7,5-fused rings instead of [4,3,1]bicyclodecane ring could be explained by the chelation model in a conformer II, while conformer I suffers a severe 1,3-diaxial interaction. Similar sequence of reactions also led to a 8,5-fused ring 37 in $72 \%$ yield, starting from 19 that was synthesized via gold-catalyzed tandem cyclization (entry 6 , Table 1 ).

We next explored the synthetic application of the iodocycliza- 


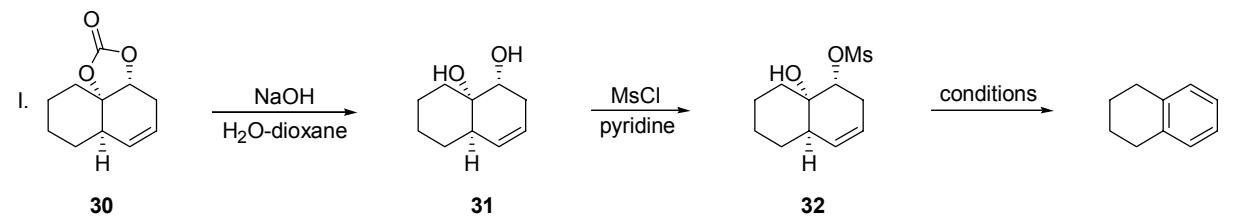

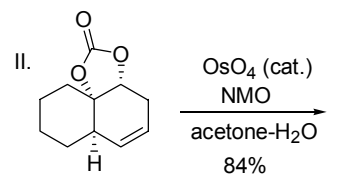

30

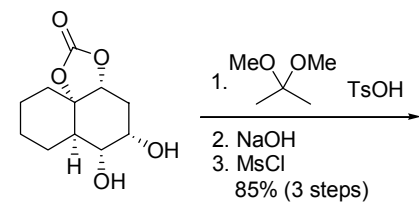

33

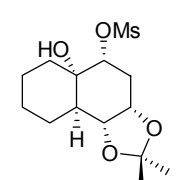

34

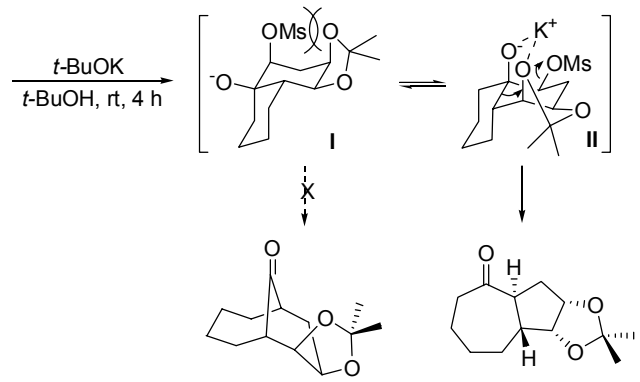

$35,79 \%$

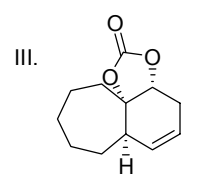

19

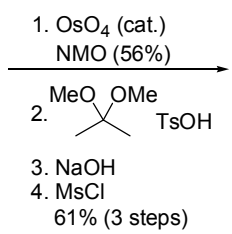

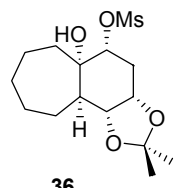

36

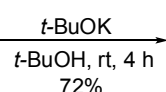

$72 \%$

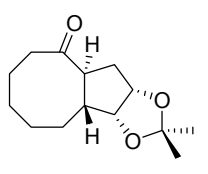

37

Scheme 5. Synthesis of 7,5- and 8,5-fused carbocycles
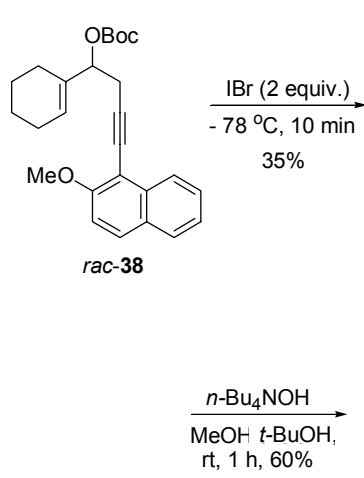
$\mathrm{rt}, 1 \mathrm{~h}, 60 \%$

separable isomers $(1.0: 1.1)$ $97 \%$

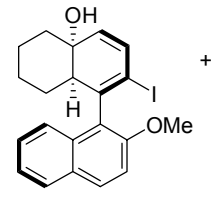

43

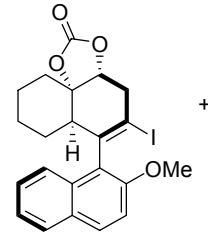

39 inseparable mixture $(M / P=1.0: 1.1)$

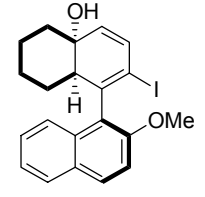

44 $\downarrow \begin{aligned} & \mathrm{TsOH} \cdot \mathrm{H}_{2} \mathrm{O} \\ & \text { toluene, } 80^{\circ} \mathrm{C}\end{aligned} \quad \downarrow 96 \%$

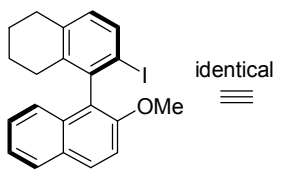

rac-45

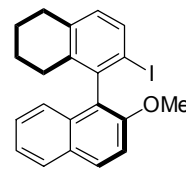

rac-45
Scheme 6. Synthesis of atropisomeric biaryls and their transformations

tion product. When the 1,5-enyne 38 bearing a bulky 2-methoxy-1-naphthyl group reacted with $\mathrm{IBr}$, an inseparable mixture of isomeric products formed (ratio $=1.0: 1.1$ ) in $35 \%$ yield. We assigned this isomeric mixture as atrop-diastereomeric pair 39/39' (Scheme 6). At this point, however, the structural identity

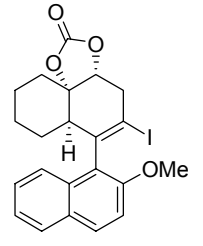

39

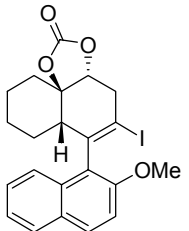

40

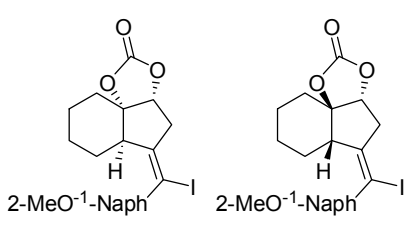

42
Figure 1. Possible structures for the isomeric products from the tandem iodocyclization of $\mathbf{3 8}$.

of this mixture was uncertain and several possible isomeric forms could also account for the observed spectra (Figure 1).

To confirm the identity of this mixture and to explore the synthetic application of the product, we converted the mixture 39/39' into the alcohol 43/44 via deprotection of carbonate and base-promoted elimination. From this, two isomers 43 and 44 were obtained that were separable by silica gel chromatography (1.0:1.1 ratio), which eliminate the possibility of 39/40 or $\mathbf{4 1 / 4 2}$ pair for original isomers 39/39'. The product 43 and 44 was then separately dehydrated to form an aromatized product 45. In this sequence, both products from 43 and 44 had identical spectra and chromatographic property, which confirms that the original inseparable isomers (39/39') were not 39/41 (or 39/42), but an atropisomeric mixture having structures 39/39' shown in Scheme 6. This atropisomerism in 39/39' probably results from a restricted rotation around the axis connecting biaryls due to steric hindrance between the methoxy and the iodo group. In principle, upon the availability of a single enantiomer of $\mathbf{3 8}$, both forms of enantiopure tetrahydrobinaphthyl iodide $\mathbf{4 5}$ would be available from one enantiomer of $\mathbf{3 8}$ and these products should 
be potential precursors of modified MOP ligand. ${ }^{7}$

In summary, we reported herein the comparative study of 1,5enyne cyclization terminating with $t$-Boc trapping, under the $\mathrm{Au}(\mathrm{I})$-catalysis and IBr. From this study evolved a mechanistic model that successfully accounts for the observed high diastereoselectivity in both cyclization protocols. In addition, potential applications of the resulting products were explored and we have shown that these methods are effective for the synthesis of 7,5trans-fused bicycle as well as atropisomeric biaryl compounds.

\section{Experimental}

Anhydrous dichloromethane and 1,2-dichloroethane (reagent grade) was purified by distillation over calcium hydride. Anhydrous THF was distilled over sodium-benzophenone ketyl. All commercially available reagents were used without further purification. Flash column chromatography was performed on Kieselgel 60 (230 - 400 mesh) and TLC analysis was carried out on Merck silica gel $60 \mathrm{~F}_{254}$ plates. ${ }^{1} \mathrm{H}$ and ${ }^{13} \mathrm{C}$ NMR spectra were recorded on a Varian $\left({ }^{1} \mathrm{H}\right.$ at $\left.400 \mathrm{MHz}\right)$ spectrometer with TMS as an internal standard. 2D-NMR experiments were conducted on Varian $(600 \mathrm{MHz})$ at Seoul National University. Elemental analyses and HRMS experiments were conducted at Sogang University, Korea Basic Science Institute, and Seoul National University.

\section{Synthesis of substrates.}

(E)-tert-Butyl 3-methyl-7-phenylhept-2-en-6-ynyl carbonate (2): To a solution of aldehyde ${ }^{5 \mathrm{a}}$ (470 $\mathrm{mg}, 2.76 \mathrm{mmol}$ ) in $\mathrm{MeOH}$ $(10 \mathrm{~mL})$ at $0{ }^{\circ} \mathrm{C}$ was added Bestmann reagent $(795.7 \mathrm{mg}, 4.14$ $\mathrm{mmol}$ ) and $\mathrm{K}_{2} \mathrm{CO}_{3}(762 \mathrm{mg}, 5.52 \mathrm{mmol})$. The mixture was slowly warmed to rt over $2 \mathrm{~h}$ while stirring. The solvent was removed under vacuum and the residue was purified by chromatography (EtOAc:Hex = 1:3) to get $390 \mathrm{mg}(85 \%)$ of the corresponding alkyne as a colorless oil; A solution of this alkyne $(200 \mathrm{mg}, 1.20$ $\mathrm{mmol}$ ), iodobenzene (368 mg, $1.80 \mathrm{mmol}), \mathrm{CuI}(9.2 \mathrm{mg}, 0.048$ $\mathrm{mmol}), \mathrm{Pd}\left(\mathrm{PPh}_{3}\right)_{2} \mathrm{Cl}_{2}(16.8 \mathrm{mg}, 0.024 \mathrm{mmol})$ and $\mathrm{K}_{2} \mathrm{CO}_{3}(664$ $\mathrm{mg}, 4.81 \mathrm{mmol})$ in THF $(10 \mathrm{~mL})$ was stirred at $\mathrm{rt}$ for $6 \mathrm{~h}$. The solvent was removed and the crude oil of acetate was dissolved in $\mathrm{MeOH}(10 \mathrm{~mL})$, then treated with $\mathrm{K}_{2} \mathrm{CO}_{3}$ (249.4 mg, 1.80 $\mathrm{mmol})$ at rt. The mixture was stirred at $\mathrm{rt}$ for $4 \mathrm{~h}$ and was filtered through a Celite pad $(3 \mathrm{~cm})$, eluting with ether. The solvent was removed and the residue was purified by chromatography $($ EtOAc:Hex $=1: 4)$ to give deprotected alcohol $1(180.6 \mathrm{mg}$, $74 \%$ ). The alcohol 1 (180.6 mg, $0.902 \mathrm{mmol})$ was dissolved in ether $(2 \mathrm{~mL})$ and was treated with $n$-BuLi $(0.620 \mathrm{~mL}$ of $1.6 \mathrm{M}$ solution in hexane) at $-78{ }^{\circ} \mathrm{C}$. After stirring for $30 \mathrm{~min}$, the resulting lithium alkoxide solution was transferred to a solution of 2-(tert-butoxycarbonyloxyimino)-2-phenylacetonitrine (BocOn) $(244.3 \mathrm{mg}, 0.992 \mathrm{mmol})$ in $\mathrm{THF}(1.0 \mathrm{~mL})$ at $0{ }^{\circ} \mathrm{C}$. The resulting mixture was allowed to stir at rt overnight. The reaction was quenched by addition of aqueous saturated $\mathrm{NH}_{4} \mathrm{Cl}(3 \mathrm{~mL})$ and the aqueous layer was extracted with ether $(3 \mathrm{~mL} \times 3)$. The combined organic extracts were dried, evaporated and the residue was purified by chromatography (EtOAc:Hex =1:12) to give $167 \mathrm{mg}(62 \%)$ of 2 as colorless oil. ${ }^{1} \mathrm{H} \mathrm{NMR} \mathrm{(400} \mathrm{MHz,}$ $\left.\mathrm{CDCl}_{3}\right) \delta 7.42-7.35(\mathrm{~m}, 2 \mathrm{H}), 7.31-7.24(\mathrm{~m}, 3 \mathrm{H}), 5.48(\mathrm{t}, J=5.9$ $\mathrm{Hz}, \mathrm{H}), 4.61(\mathrm{~d}, J=6.9 \mathrm{~Hz}, 2 \mathrm{H}), 2.53(\mathrm{t}, J=7.3 \mathrm{~Hz}, 2 \mathrm{H}), 2.34(\mathrm{t}$, $J=7.3 \mathrm{~Hz}, 2 \mathrm{H}), 1.76(\mathrm{~s}, 3 \mathrm{H}), 1.48(\mathrm{~s}, 9 \mathrm{H}) ;{ }^{13} \mathrm{C} \mathrm{NMR}(100 \mathrm{MHz}$,
$\left.\mathrm{CDCl}_{3}\right) \delta 154.2,141.4,132.2,128.8,128.2,124.4,120.0,90.0$, $82.6,81.8,64.2,39.0,28.4,18.8,17.1$.

tert-Butyl 2-methylene-6-phenylhex-5-ynyl carbonate (4): To a solution of 2-( $\left.\mathrm{TMSCH}_{2}\right)$ prop-2-ene-1-ol $\mathbf{3}^{5 \mathrm{c}}$ (288.6 mg, 2.00 $\mathrm{mmol})$ in THF $(3 \mathrm{~mL})$ at $0^{\circ} \mathrm{C}$ was added $n-\mathrm{BuLi}(1.25 \mathrm{~mL}$ of 1.6 M solution, $2.00 \mathrm{mmol})$. After $30 \mathrm{~min}$ at $0{ }^{\circ} \mathrm{C}$, the color changes from pale yellow to orange. To the mixture was added 1-(3-bromo-1-propynyl)benzene ( $975.3 \mathrm{mg}, 5.00 \mathrm{mmol})$ in THF $(8 \mathrm{~mL})$ at $0{ }^{\circ} \mathrm{C}$ and then the resulting dark brown solution was treated with $2 \mathrm{~mL}$ of HMPA. The mixture was allowed to stir overnight at $\mathrm{rt}$. The reaction was quenched by addition of $0.5 \mathrm{~N} \mathrm{HCl} \mathrm{(10}$ $\mathrm{mL}$ ) and stirring at $\mathrm{rt}$ for $1 \mathrm{~h}$. The aqueous layer was extracted with ether $(10 \mathrm{~mL} \times 4)$. After drying $\left(\mathrm{MgSO}_{4}\right)$ and evaporation of solvent, the residue was purified by chromatography (EtOAc: Hex $=1: 4)$ to get $114.0 \mathrm{mg}(31 \%)$ of the alcohol as a colorless oil. The $O$-Boc group was introduced following a similar procedure for 2 to give 4 (70\% yield, a colorless oil). ${ }^{1} \mathrm{H} \mathrm{NMR}(400 \mathrm{MHz}$, $\left.\mathrm{CDCl}_{3}\right) \delta$ 7.40-7.35 (m, 2H), 7.29-7.24 (m, 3H), 5.16(s, H), 5.08 $(\mathrm{s}, \mathrm{H}), 4.57(\mathrm{~s}, 2 \mathrm{H}), 2.58(\mathrm{t}, J=7.4 \mathrm{~Hz}, 2 \mathrm{H}), 2.40(\mathrm{t}, J=7.3 \mathrm{~Hz}$, 2H), $1.49(\mathrm{~s}, 9 \mathrm{H}) ;{ }^{13} \mathrm{C} \mathrm{NMR}\left(100 \mathrm{MHz}, \mathrm{CDCl}_{3}\right) \delta 154.1,142.7$, 132.2, 128.8, 128.3, 124.4, 114.7, 89.8, 82.8, 81.9, 69.8, 32.8, $28.4,18.8$.

tert-Butyl 6-methylene-10-phenyldec-9-yn-5-yl carbonate (7): To a solution of $3(288 \mathrm{mg}, 2.00 \mathrm{mmol})$ in ether $(20 \mathrm{~mL})$ was treated with $\mathrm{MnO}_{2}(0.870 \mathrm{~g}, 10.0 \mathrm{mmol})$ at rt. After $10 \mathrm{~h}$, the mixture was filtered through Celite pad and rinsed with ether. The solvent was removed by simple distillation apparatus under atmospheric pressure (bath temperature, $70{ }^{\circ} \mathrm{C}$ ). The residue was re-dissolved in THF $(10 \mathrm{~mL})$ and $n-B u L i ~(1.50 \mathrm{~mL}$ of $1.6 \mathrm{M}$ soln, $2.40 \mathrm{mmol}$ ) was added to the mixture at $-78^{\circ} \mathrm{C}$. After $30 \mathrm{~min}$, it was treated with a solution of 1-(3-bromo-1-propynyl)benzene $(1.17 \mathrm{~g}, 6.00 \mathrm{mmol})$ in THF/HMPA $(10 \mathrm{~mL} / 1.4 \mathrm{~mL})$ dropwise at $-78^{\circ} \mathrm{C}$. The mixture was warmed to rt over $20 \mathrm{~min}$ and quenched with $0.5 \mathrm{~N} \mathrm{HCl}(20 \mathrm{~mL})$. The aqueous layer was extracted with ether $(20 \mathrm{~mL} \times 3)$ and the combined organic layers were dried $\left(\mathrm{MgSO}_{4}\right)$, evaporated and the residue was purified by chromatography (EtOAc/Hex $=1: 8)$ to give $198.3 \mathrm{mg}(49 \%$, over 2 steps) of $\mathbf{6}$ as pale yellow oil. The $O$-Boc group was introduced following a similar procedure for 2 to give 7 (71\%). ${ }^{1} \mathrm{H}$ NMR (400 $\left.\mathrm{MHz}, \mathrm{CDCl}_{3}\right) \delta$ 7.40-7.35 (m, 2H), 7.29-7.24 (m, 3H), $5.14(\mathrm{~s}$, $\mathrm{H}), 5.02(\mathrm{~s}, \mathrm{H}), 4.97(\mathrm{t}, J=6.6 \mathrm{~Hz}, \mathrm{H}), 2.62-2.55(\mathrm{~m}, 2 \mathrm{H}), 2.37$ (q, $J=6.6 \mathrm{~Hz}, 2 \mathrm{H}), 1.74-1.60(\mathrm{~m}, 2 \mathrm{H}), 1.47$ (s, 9H), 1.38-1.25 (m, $4 \mathrm{H}), 0.88(\mathrm{t}, J=6.6 \mathrm{~Hz}, 3 \mathrm{H}) ;{ }^{13} \mathrm{C}$ NMR $\left(100 \mathrm{MHz}, \mathrm{CDCl}_{3}\right) \delta$ 153.7, 146.5, 132.2, 128.8, 128.2, 124.5, 113.1, 90.1, 82.5, 81.6, $80.7,33.6,31.4,28.5,28.3,23.1,18.8,14.6$.

8-Aryl-2-benzyl-4-methyleneoct-7-ynoic acid (10): The solution of 1 ( $330 \mathrm{mg}, 1.53 \mathrm{mmol})$, triethyl orthoacetate (1.67 $\mathrm{mL}, 9.16 \mathrm{mmol})$ and propionic acid $(5.6 \mathrm{mg}, 0.076 \mathrm{mmol})$ in xylene $(50 \mathrm{~mL})$ was heated under reflux (bath temp, $\left.135^{\circ} \mathrm{C}\right)$. After $6.5 \mathrm{~h}$, the mixture was washed with saturated $\mathrm{NaHCO}_{3}$ $(5 \mathrm{~mL})$ and was evaporated to dryness. The residue was purified by chromatography (EtOAc:Hex $=1: 6)$ to give $8(428.2 \mathrm{mg}$, $98 \%)$ as an oil. To a solution of the ethyl ester $8(57.3 \mathrm{mg}, 0.200$ mmol) dissolved in THF $(3 \mathrm{~mL})$ at $-78^{\circ} \mathrm{C}$, was added dropwise LiHMDS ( $0.150 \mathrm{~mL}$ of $1.6 \mathrm{M}$ soln, $0.240 \mathrm{mmol})$. After $30 \mathrm{~min}$ at $-78{ }^{\circ} \mathrm{C}$, benzyl bromide $(30.9 \mu \mathrm{L}, 0.260 \mathrm{mmol})$ was added. The mixture was slowly warmed to rt over $2 \mathrm{~h}$. Purification by chromatography (EtOAc:Hex = 1:4) gave $37.3 \mathrm{mg}(50 \%)$ of $\alpha$ - 
benzylated ester. This ethyl ester $(37.3 \mathrm{mg}, 0.099 \mathrm{mmol})$ was hydrolyzed in THF/MeOH/water $(1: 1: 1,1 \mathrm{~mL})$ using $\mathrm{LiOH} \cdot \mathrm{H}_{2} \mathrm{O}$ (4.6 mg, $0.11 \mathrm{mmol}$ ). After $1 \mathrm{~h}$, the mixture was filtered through a short silica gel, rinsing with EtOAc. The solvent was removed and the residue was purified by chromatography (EtOAc:Hex $=$ $1 / 2,3 \% \mathrm{MeOH})$ to give $25.5 \mathrm{mg}(74 \%)$ of $\mathbf{1 0} .{ }^{1} \mathrm{H}$ NMR (400 $\left.\mathrm{MHz}, \mathrm{CDCl}_{3}\right) \delta 7.34-7.15(\mathrm{~m}, 7 \mathrm{H}), 6.79(\mathrm{~d}, J=8.4 \mathrm{~Hz}, 2 \mathrm{H}), 4.91$ $(\mathrm{s}, \mathrm{H}), 4.89(\mathrm{~s}, \mathrm{H}), 3.78(\mathrm{~s}, 3 \mathrm{H}), 3.02-2.86(\mathrm{~m}, 2 \mathrm{H}), 2.85-2.76(\mathrm{~m}$, $\mathrm{H}), 2.58-2.40(\mathrm{~m}, 3 \mathrm{H}), 2.38-2.22(\mathrm{~m}, 3 \mathrm{H}),{ }^{13} \mathrm{C} \mathrm{NMR}(100 \mathrm{MHz}$, $\left.\mathrm{CDCl}_{3}\right) \delta 181.4,159.7,145.3,139.4,133.5,129.5,129.1,127.2$, 116.6, 114.4, 113.1, 88.4, 81.4, 55.9, 46.6, 38.9, 38.6, 35.5, 18.8 .

A representative procedure for $\mathrm{Au}(\mathrm{I})$-catalyzed cyclization (12). To a solution of $\mathrm{Au}[t-\mathrm{Bu} 2 \mathrm{P}(o$-biphenyl $)] \mathrm{Cl}(3.1 \mathrm{mg}, 0.0059$ $\mathrm{mmol})$ and $\mathrm{AgSbF}_{6}(2.0 \mathrm{mg}, 0.0059 \mathrm{mmol})$ in 1,2-dichloroethane $(0.5 \mathrm{~mL})$ at room temperature, was added a solution of enyne $4(68.2 \mathrm{mg}, 0.238 \mathrm{mmol})$ in 1,2-dichloroethane $(0.6 \mathrm{~mL})$. After stirring the mixture for $20 \mathrm{~min}$, the reaction was quenched by the addition of triethylamine ( $20 \mathrm{mg})$. Solvent was removed under vacuum and the residue was purified by flash chromatography (EtOAc:Hex = 1:9) to get 12 (49.9 mg, 91\%) as offwhite solid.

(11): A white solid (mp $\left.129-131^{\circ} \mathrm{C}\right)$; IR (NaCl) 2940, 2836, 1750, 1500, 1403, 1300, 1196, 1133, $1092 \mathrm{~cm}^{-1} ;{ }^{1} \mathrm{H}$ NMR (400 $\left.\mathrm{MHz}, \mathrm{CDCl}_{3}\right) \delta$ 7.39-7.29 (m, 3H), 7.20-7.12 (m, 2H), 5.85-5.72 $(\mathrm{m}, \mathrm{H}), 4.45(\mathrm{dd}, J=5.9,11.0 \mathrm{~Hz}, \mathrm{H}), 3.97(\mathrm{dd}, J=11.0,13.2 \mathrm{~Hz}$, H), 3.44-3.30 (m, H), 2.62-2.47 (m, H), 2.43-2.25 (m, H), 2.12$1.94(\mathrm{~m}, 2 \mathrm{H}), 1.47(\mathrm{~s}, 3 \mathrm{H}) ;{ }^{13} \mathrm{C}$ NMR $\left(100 \mathrm{MHz}, \mathrm{CDCl}_{3}\right) \delta$ 140, 149.6, 139.3, 135.0, 129.2, 128.4, 128.0, 127.5, 81.2, 69.6, 40.7, 34.5, 24.9, 19.0; Anal Calcd for $\mathrm{C}_{15} \mathrm{H}_{16} \mathrm{O}_{3}$ : C 73.75, H 6.60; found: C 73.71, H 6.45 .

(12): A white solid (mp $\left.129-131^{\circ} \mathrm{C}\right)$; IR (NaCl) 2933, 2843, 1791, 1438, 1383, 1182, $1064 \mathrm{~cm}^{-1} ;{ }^{1} \mathrm{H}$ NMR (400 MHz, $\mathrm{CDCl}_{3}$ )

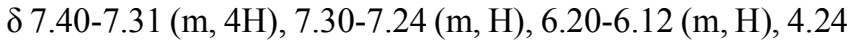
$(\mathrm{ABq}, J=8.4 \mathrm{~Hz}, 2 \mathrm{H}), 2.89(\mathrm{ABq}, J=17.3 \mathrm{~Hz}, \mathrm{H}), 2.72(\mathrm{ABq}$, $J=17.3 \mathrm{~Hz}, \mathrm{H}), 2.66-2.48$ (m, H), 2.47-2.27 (m, H), 2.14 (td, $J=6.6,12.8 \mathrm{~Hz}, \mathrm{H}), 1.92(\mathrm{td}, J=5.9,12.5 \mathrm{~Hz}, \mathrm{H}) ;{ }^{13} \mathrm{C} \mathrm{NMR}(100$ $\left.\mathrm{MHz}, \mathrm{CDCl}_{3}\right) \delta 140.9,133.3,129.1,128.1,125.7,124.1,82.8$, 74.9, 38.0, 31.2, 23.4; Anal Calcd for $\mathrm{C}_{14} \mathrm{H}_{14} \mathrm{O}_{3}$ : C 73.03, H 6.13; found: C 73.02, H 6.23 .

(13): A colorless solid (mp $\left.89-91^{\circ} \mathrm{C}\right)$; IR (NaCl) 3033, 2913, 1770, 1493, 1445, 1230, 1175, $1064 \mathrm{~cm}^{-1}$; ${ }^{1} \mathrm{H}$ NMR (400 MHz, $\left.\mathrm{CDCl}_{3}\right) \delta$ 7.42-7.29 (m, 4H), 7.28-7.20 (m, H), 6.20-6.08 (m, H), 2.86-2.74 (m, H), 2.74-2.62 (m, 3H), 2.58-2.46 (m, H), 2.45$2.28(\mathrm{~m}, \mathrm{H}), 2.13(\mathrm{dt}, J=1.8,8.4 \mathrm{~Hz}, 2 \mathrm{H}), 2.03(\mathrm{td}, J=6.6,12.8$ $\mathrm{Hz}, \mathrm{H}) 1.79(\mathrm{td}, J=6.3,12.9 \mathrm{~Hz}, \mathrm{H}) ;{ }^{13} \mathrm{C}$ NMR $(100 \mathrm{MHz}$, $\left.\mathrm{CDCl}_{3}\right) \delta 141.6,134.1,129.0,127.8,125.6,124.2,85.6,39.5$, 33.0, 32.8, 29.2, 24.1; Anal Calcd for $\mathrm{C}_{15} \mathrm{H}_{16} \mathrm{O}_{2}$ : C 78.92, H 7.06; found: C 78.91, H 6.95 .

(15): Pale yellow solid (mp $95-96^{\circ} \mathrm{C}$ ); IR (NaCl) 2982, 2926, 2850, 1784, 1597, 1514, 1459, 1355, 1251, 1113, 1043; ${ }^{1} \mathrm{H}$ NMR $\left(400 \mathrm{MHz}, \mathrm{CDCl}_{3}\right) \delta 7.29(\mathrm{~d}, J=8.8 \mathrm{~Hz}, 2 \mathrm{H}), 6.86(\mathrm{~d}, J=8.4 \mathrm{~Hz}$, $2 \mathrm{H}), 5.94(\mathrm{~d}, J=5.1 \mathrm{~Hz}, \mathrm{H}), 4.63(\mathrm{~d}, J=4.1 \mathrm{~Hz}, \mathrm{H}), 3.81(\mathrm{~s}, 3 \mathrm{H})$, 3.09 (q, $J=7.4 \mathrm{~Hz}, \mathrm{H}), 2.67$ (dd, $J=7.0,17.2 \mathrm{~Hz}, \mathrm{H}), 2.52$ (d br, $J=17.6 \mathrm{~Hz}, \mathrm{H}), 1.64(\mathrm{~s}, 3 \mathrm{H}), 1.09(\mathrm{~d}, J=7.3 \mathrm{~Hz}, 3 \mathrm{H}) ;{ }^{13} \mathrm{C} \mathrm{NMR}$ $\left(100 \mathrm{MHz} \mathrm{CDCl}_{3}\right) \delta 159.9,155.0,144.1,133.1,127.4,117.3$, 114.5, 86.6, 81.1, 55.9, 41.1, 28.8, 25.5, 14.1; Anal Calcd for $\mathrm{C}_{16} \mathrm{H}_{18} \mathrm{O}_{4}$ : C 70.06, H 6.61; found: C 70.12, H 6.64.

(19): A colorless solid (mp 65-67 $\left.{ }^{\circ} \mathrm{C}\right)$; IR (NaCl) 2926, 2850,
1791, 1445, 1362, 1237, 1189, $1036 \mathrm{~cm}^{-1} ;{ }^{1} \mathrm{H}$ NMR (400 MHz, $\left.\mathrm{CDCl}_{3}\right) \delta 6.00-5.89(\mathrm{~m}, \mathrm{H}), 5.82-5.70(\mathrm{~m}, \mathrm{H}), 4.44(\mathrm{t}, J=4.0 \mathrm{~Hz}$, $\mathrm{H}), 2.63(\mathrm{t}, J=7.0 \mathrm{~Hz}, \mathrm{H}), 2.45(\mathrm{td}, J=3.6,16.9 \mathrm{~Hz}, \mathrm{H}), 2.37$ (d, $J=16.9 \mathrm{~Hz}, \mathrm{H}), 2.16(\mathrm{dd}, J=8.8,15.0 \mathrm{~Hz}, \mathrm{H}), 1.92-1,76(\mathrm{~m}, 3 \mathrm{H})$, $1.76-1.62(\mathrm{~m}, 3 \mathrm{H}), 1.56-1.45(\mathrm{~m}, 2 \mathrm{H}), 1.39-1.30(\mathrm{~m}, \mathrm{H}) ;{ }^{13} \mathrm{C}$ $\operatorname{NMR}\left(100 \mathrm{MHz}, \mathrm{CDCl}_{3}\right) \delta 155.2,133.5,122.5,88.7,82.8,44.0$, 40.3, 30.4, 29.8, 29.0, 27.0, 22.6; Anal Calcd for $\mathrm{C}_{12} \mathrm{H}_{16} \mathrm{O}_{3}$ : C 69.21, H 7.74; found: C 69.10, H 7.83.

A representative procedure for $\mathrm{IBr}$-promoted cyclization (20/21). To a solution of $2(60.0 \mathrm{mg}, 0.200 \mathrm{mmol})$ in dichloromethane $(1.0 \mathrm{~mL})$ at $-78^{\circ} \mathrm{C}$ was added dropwise a solution of $\operatorname{IBr}(82.7 \mathrm{mg}, 0.400 \mathrm{mmol})$ in dichloromethane $(1.0 \mathrm{~mL})$. The mixture was kept stirred at $-78{ }^{\circ} \mathrm{C}$ for $20 \mathrm{~min}$, then aqueous saturated $\mathrm{Na}_{2} \mathrm{~S}_{2} \mathrm{O}_{3}(4 \mathrm{~mL})$ was added at once. The mixture was allowed to warm to room temperature with stirring. Layers were separated and the aqueous layer was extracted with dichloromethane $(4 \mathrm{~mL} \times 3)$. The combined organic layers were dried $\left(\mathrm{MgSO}_{4}\right)$, evaporated, and the residue was purified by silica gel chromatography (EtOAc:Hex $=1: 6$ ) to yield $22.1 \mathrm{mg}$ of $\mathbf{2 0}$ (30\%) along with $60.8 \mathrm{mg}$ of $21(60 \%)$.

(20): A white solid (mp $\left.138-140^{\circ} \mathrm{C}\right)$; IR (NaCl) 2916, 2845, $1748,1393,1190,1100 \mathrm{~cm}^{-1} ;{ }^{1} \mathrm{H}$ NMR $\left(600 \mathrm{MHz}, \mathrm{CDCl}_{3}\right) \delta$ 7.46-7.36 (m, 3H), 7.08 (d, $J=7.3 \mathrm{~Hz}, \mathrm{H}), 7.00-6.95$ (m, H), $4.10(\mathrm{dd}, J=11.1,13.2 \mathrm{~Hz}, \mathrm{H}), 3.87$ (dd, $J=6.0,11.0 \mathrm{~Hz}, \mathrm{H})$, 3.28-3.19 (m, H), 3.09 (dd, $J=7.2,18.9 \mathrm{~Hz}, \mathrm{H}), 2.96-2.84$ (m, H), 2.27-2.18 (m, H), 1.97 (dd, $J=6.9,12.6 \mathrm{~Hz}, \mathrm{H}), 1.54(\mathrm{~s}, 3 \mathrm{H})$; ${ }^{13} \mathrm{C}$ NMR $\left(100 \mathrm{MHz}, \mathrm{CDCl}_{3}\right) \delta 148.8,141.3,139.3,129.7$, 129.3, 129.1, 129.0, 127.6, 101.4, 79.7, 69.4, 43.5, 40.1, 37.6, 19.2; HRMS-ES: $m / z$ calculated for $\mathrm{C}_{15} \mathrm{H}_{15} \mathrm{IO}_{3} \mathrm{Na}[\mathrm{M}+\mathrm{Na}]^{+}$: 392.9964, found 392.9959. (Structure was based on COSY and 1D-NOE spectra. The selected NOE contacts as well as vicinal $J_{1,2}$ constants of $\mathrm{OCH}_{2}$ protons $\left(\mathrm{H}_{\mathrm{a}}: J=13.6 \mathrm{~Hz}, \mathrm{H}_{\mathrm{e}}: J=5.9 \mathrm{~Hz}\right)$ supports trans-ring junction.)

(21): A pale yellow liquid; IR (NaCl) 2978, 2926, 1743, 1450, $1365,1270,1246,1161,1104 \mathrm{~cm}^{-1} ;{ }^{1} \mathrm{HNMR}\left(400 \mathrm{MHz}, \mathrm{CDCl}_{3}\right)$ $\delta 7.42-7.30(\mathrm{~m}, 3 \mathrm{H}), 7.16(\mathrm{~d}, J=6.6 \mathrm{~Hz}, 2 \mathrm{H}), 4.00(\mathrm{~d}, J=4.0 \mathrm{~Hz}$, 2H), 3.24 ( $\mathrm{s} \mathrm{br}, \mathrm{H}), 3.14-3.02(\mathrm{~m}, \mathrm{H}), 2.92(\mathrm{dd}, \mathrm{J}=6.2,18.3 \mathrm{~Hz}$, H), 2.22-2.10 (m, H), 2.02-1.96 (m, H), 1.96 (s, 3H), 1.44 (s, $9 \mathrm{H}) ;{ }^{13} \mathrm{C}$ NMR $\left(100 \mathrm{MHz}, \mathrm{CDCl}_{3}\right) \delta 153.5,145.4,141.3,129.1$, 128.9, 128.3, 102.2, 83.1, 68.0, 65.0, 56.4, 41.0, 39.2, 32.5, 28.4; LRMS (CI+) calcd for $\mathrm{C}_{19} \mathrm{H}_{24}{ }^{79} \mathrm{BrIO}_{3}\left[\mathrm{M}^{+}\right] 506$, found 451(1) $\left[\mathrm{M}^{+}+\mathrm{H}-\mathrm{C}_{4} \mathrm{H}_{8},{ }^{79} \mathrm{Br}\right], 453(1)\left[\mathrm{M}^{+}+\mathrm{H}-\mathrm{C}_{4} \mathrm{H}_{8},{ }^{81} \mathrm{Br}\right], 389(14)\left[\mathrm{M}^{+}-\right.$ BocO, $\left.{ }^{79} \mathrm{Br}\right], 391(15)\left[\mathrm{M}^{+}-\mathrm{BocO},{ }^{81} \mathrm{Br}\right], 371(67)\left[\mathrm{M}^{+}-\mathrm{C}_{4} \mathrm{H}_{8}-\mathrm{Br}\right]$, 309(100) [ $\left.\mathrm{M}^{+}-\mathrm{BocOH}-\mathrm{Br}\right]$.

(22): A pale yellow solid (mp $113-114^{\circ} \mathrm{C}$ ) IR ( $\left.\mathrm{NaCl}\right): 2926$, 2850, 1790, 1492, 1436, 1388, 1232, 1175, $1062 \mathrm{~cm}^{-1} ;{ }^{1} \mathrm{H}$ NMR $\left(400 \mathrm{MHz}, \mathrm{CDCl}_{3}\right) \delta 7.42-7.30(\mathrm{~m}, 3 \mathrm{H}), 7.16-7.12(\mathrm{~m}, 2 \mathrm{H}), 4.27$ (d of AB q, $J=8.8 \mathrm{~Hz}, \mathrm{H}$ ), 4.20 (d of AB q, $J=8.5 \mathrm{~Hz}, \mathrm{H}$ ), 3.153.04 (m, H), 2.96-2.82 (m, 2H), 2.76-2.67 (m, H), 2.18-2.10 (m, $\mathrm{H}), 2.05-1.96(\mathrm{~m}, \mathrm{H}) ;{ }^{13} \mathrm{C}$ NMR $\left(100 \mathrm{MHz}, \mathrm{CDCl}_{3}\right) \delta 154.7$, 145.1, 139.9, 129.2, 128.5, 128.4, 97.1, 81.5, 74.6, 43.3, 38.3, 34.2; Anal Calcd for $\mathrm{C}_{14} \mathrm{H}_{13} \mathrm{IO}_{3}$ : C 47.21, H 3.68; found: C 47.21, H 3.84 .

(23): A pale yellow liquid; IR (NaCl) 2973, 2921, 2850, 1738, $1369,1275,1256,1161 \mathrm{~cm}^{-1} ;{ }^{1} \mathrm{H}$ NMR $\left(400 \mathrm{MHz}, \mathrm{CDCl}_{3}\right) \delta$ 7.40-7.28 (m, 3H), 7.17-7.12 (m, 2H), 4.36 (ABq, $J=11.4,14.9$ $\mathrm{Hz}, 2 \mathrm{H}), 3.18-3.02(\mathrm{~m}, 2 \mathrm{H}), 3.00-2.95(\mathrm{~m}, 2 \mathrm{H}), 2.16-2.06(\mathrm{~m}$, $\mathrm{H}), 2.04-1.96(\mathrm{~m}, \mathrm{H}), 1.48(\mathrm{~s}, 9 \mathrm{H}) ;{ }^{13} \mathrm{C} \mathrm{NMR}\left(100 \mathrm{MHz}, \mathrm{CDCl}_{3}\right)$ 
$\delta 153.6,145.9,140.6,129.0,128.5,128.2,96.9,83.5,74.1,63.6$, 45.6, 40.0, 36.2, 28.4; LRMS (CI+) calcd for $\mathrm{C}_{18} \mathrm{H}_{22}{ }^{79} \mathrm{BrIO}_{3}$ $\left[\mathrm{M}^{+}+\mathrm{H}\right]$ 493, found 493(2) $\left[\mathrm{M}^{+}+\mathrm{H},{ }^{79} \mathrm{Br}\right], 495(2)\left[\mathrm{M}^{+}+\mathrm{H},{ }^{81} \mathrm{Br}\right]$, $375(64)\left[\mathrm{M}^{+}-\mathrm{BocO},{ }^{79} \mathrm{Br}\right], 377(59)\left[\mathrm{M}^{+}-\mathrm{BocO},{ }^{81} \mathrm{Br}\right], 357(46)$ $\left[\mathrm{M}^{+}-\mathrm{Br}-\mathrm{C}_{4} \mathrm{H}_{8}\right], 295(100)\left[\mathrm{M}^{+}-\mathrm{Br}-\mathrm{BocOH}\right]$.

(24): (obtained as an inseparable 3:1 mixture of diastereomers): A pale yellow solid; IR ( NaCl) 2926, 2845, 1771, 1606, $1511,1454,1242,1180,1038 \mathrm{~cm}^{-1} ;{ }^{1} \mathrm{HNMR}\left(400 \mathrm{MHz}, \mathrm{CDCl}_{3}\right)$ $\delta 7.36-7.28(\mathrm{~m}, 2 \mathrm{H}), 7.25-7.16(\mathrm{~m}, 3 \mathrm{H}), 7.07-7.02(\mathrm{~m}, 2 \mathrm{H})$, and 6.91-6.85 (m, 2H) for aromatic protons (major and minor), 3.81 and $3.80(\mathrm{~s}, 3 \mathrm{H}, 3: 1$ ratio) for -OMe of major and minor, 3.29 (dd, $J=4.4,14.0 \mathrm{~Hz}, \mathrm{H}), 3.15-3.04(\mathrm{~m}, \mathrm{H}), 3.04-2.92(\mathrm{~m}, \mathrm{H})$, 2.85-2.76 (m, 2H), 2.59-2.49 (m, 2H), 2.23-2.15 (m, H), 1.96$1.86(\mathrm{~m}, \mathrm{H}), 1,85-1.73(\mathrm{~m}, 2 \mathrm{H}) ;{ }^{13} \mathrm{C} \mathrm{NMR}\left(100 \mathrm{MHz}, \mathrm{CDCl}_{3}\right) \delta$ $178.1,159.5,140.4,139.0,138.2,129.7 / 129.6,129.5,129.4$, 127.5, 114.3/114.2, 97.4, 82.3/82.2, 55.8, 46.0, 42.4, 39.2, 39.0, $37.3 / 37.2,35.0$ (underlined peaks are from the minor isomer); HRMS-ES: $m / z$ calculated for $\mathrm{C}_{23} \mathrm{H}_{23} \mathrm{IO}_{3} \mathrm{Na}[\mathrm{M}+\mathrm{Na}]^{+}$: 497.0590, found 497.0591 .

(25): A white solid (mp $\left.65-67^{\circ} \mathrm{C}\right)$; IR (NaCl) 2959, 2940, 2865, 1795, 1360, 1275, $1185 \mathrm{~cm}^{-1}$; ${ }^{1} \mathrm{H}$ NMR (400 MHz, $\left.\mathrm{CDCl}_{3}\right): \delta 7.42-7.30(\mathrm{~m}, 3 \mathrm{H}), 7.18-7.13(\mathrm{~m}, 2 \mathrm{H}), 4.24(\mathrm{dd}, J=$ 2.6, 10.3 Hz, H), 3.10-3.00 (m, H), 2.99-2.89 (m, H), 2.76-2.62 (s br, 2H), 2.05-1.96 (m, H), 1.94-1.86 (m, H), 1.83-1.72 (m, H), $1.62-1.55(\mathrm{~m}, 2 \mathrm{H}), 1.46-1.36(\mathrm{~m}, 3 \mathrm{H}), 0.92(\mathrm{t}, J=6.6 \mathrm{~Hz}, 3 \mathrm{H})$; ${ }^{13} \mathrm{C}$ NMR $\left(100 \mathrm{MHz}, \mathrm{CDCl}_{3}\right) \delta 154.4,145.2,139.7,129.1$, $128.48,128.46,97.5,85.3,83.7,43.0,37.7,29.3,28.9,28.8$, 23.0, 14.4; Anal Calcd for $\mathrm{C}_{18} \mathrm{H}_{21} \mathrm{IO}_{3}$ : C 52.44, $\mathrm{H}$ 5.13; found: $\mathrm{C}$ 52.42, H 5.69. Structure was based on COSY and 1D-NOE spectra. The selected NOE contact for CHO proton $(\delta 4.24, \mathrm{dd})$ and isolated methylene $(\delta 2.69, \mathrm{~m})$ indicates the relative stereochemistry shown below.

(26): A white solid (mp $\left.105-107^{\circ} \mathrm{C}\right)$; IR (NaCl) 2916, 2850, 1790, 1601, 1511, 1350, 1246, $1057 \mathrm{~cm}^{-1}$; ${ }^{1} \mathrm{H}$ NMR (400 MHz, $\left.\mathrm{CDCl}_{3}\right) \delta 7.12(\mathrm{~d}, J=8.8 \mathrm{~Hz}, 2 \mathrm{H}), 6.90(\mathrm{~d}, J=8.4 \mathrm{~Hz}, 2 \mathrm{H}), 4.55$ (t, $J=3.7 \mathrm{~Hz}, \mathrm{H}), 3.82$ (s, 3H), 3.24-3.16 (m, 2H), 2.95 (q, $J=7.3$ $\mathrm{Hz}, \mathrm{H}), 1.58$ (s, 3H), 1.07 (d, $J=7.3 \mathrm{~Hz}, 3 \mathrm{H}) ;{ }^{13} \mathrm{C}$ NMR $(100$ $\left.\mathrm{MHz}, \mathrm{CDCl}_{3}\right) \delta 159.8,154.6,149.6,136.7,130.0,129.8,114.4$, 89.0, 86.0, 81.9, 55.9, 46.3, 43.8, 25.0, 13.4; HRMS-ES: $\mathrm{m} / \mathrm{z}$ calculated for $\mathrm{C}_{16} \mathrm{H}_{17} \mathrm{IO}_{4} \mathrm{Na}[\mathrm{M}+\mathrm{Na}]^{+}: 423.0069$, found 423.0068 .

(27): A pale yellow liquid; IR (NaCl) 2916, 2930, 1743, 1601, 1506, 1365, 1279, 1242, $1156 \mathrm{~cm}^{-1} ;{ }^{1} \mathrm{H}$ NMR $\left(400 \mathrm{MHz}, \mathrm{CDCl}_{3}\right)$ $\delta 7.16(\mathrm{~d}, J=8.4 \mathrm{~Hz}, 2 \mathrm{H}), 6.91(\mathrm{~d}, J=8.8 \mathrm{~Hz}, 2 \mathrm{H}), 5.49$ (dd, $J=3.3,7.7 \mathrm{~Hz}, \mathrm{H}), 4.03$ (q, $J=6.9 \mathrm{~Hz}, \mathrm{H}), 3.82$ (s, 3H), 3.37 (dd, $J=7.7,17.3 \mathrm{~Hz}, \mathrm{H}), 2.77$ (dd, $J=3.3,17.2 \mathrm{~Hz}, \mathrm{H}), 1.70$ (d, $J=$ $7.0 \mathrm{~Hz}, 3 \mathrm{H}), 1.51(\mathrm{~s}, 9 \mathrm{H}), 1.14(\mathrm{~s}, 3 \mathrm{H}) ;{ }^{13} \mathrm{C} \mathrm{NMR}(100 \mathrm{MHz}$, $\left.\mathrm{CDCl}_{3}\right) \delta 159.9,153.6,152.8,131.2,129.5,114.3,95.2,83.1$, 78.3, 60.4, 57.4, 55.8, 50.7, 28.4, 21.8, 18.7; LRMS (CI+) calcd for $\mathrm{C}_{20} \mathrm{H}_{26}{ }^{79} \mathrm{BrIO}_{4}\left[\mathrm{M}^{+}+\mathrm{H}\right]$ 537, found 537 (22) $\left[\mathrm{M}^{+}+\mathrm{H},{ }^{79} \mathrm{Br}\right]$, 539 (22) $\left[\mathrm{M}^{+}+\mathrm{H},{ }^{81} \mathrm{Br}\right], 481(26)\left[\mathrm{M}^{+}+\mathrm{H}-\mathrm{C}_{4} \mathrm{H}_{8},{ }^{79} \mathrm{Br}\right], 483(24)$ $\left[\mathrm{M}^{+}+\mathrm{H}-\mathrm{C}_{4} \mathrm{H}_{8},{ }^{81} \mathrm{Br}\right], 419(52)\left[\mathrm{M}^{+}-\mathrm{BocO},{ }^{79} \mathrm{Br}\right], 421(51)\left[\mathrm{M}^{+}-\right.$ BocO, $\left.{ }^{81} \mathrm{Br}\right], 401(100)\left[\mathrm{M}^{+}-\mathrm{Br}_{-} \mathrm{C}_{4} \mathrm{H}_{8},{ }^{79} \mathrm{Br}\right]$.

(28): A white solid (mp $\left.137-139^{\circ} \mathrm{C}\right)$; IR (NaCl) 2982, 2921, 1795, 1440, 1350, 1208, $1057 \mathrm{~cm}^{-1} ;{ }^{1} \operatorname{HNMR}\left(400 \mathrm{MHz}, \mathrm{CDCl}_{3}\right)$ $\delta 7.45-7.30(\mathrm{~m}, 3 \mathrm{H}), 7.22-7.14(\mathrm{~m}, 2 \mathrm{H}), 4.56(\mathrm{t}, J=3.6 \mathrm{~Hz}, \mathrm{H})$, 3.30-3.14 (m, 2H), 2.98 (q, $J=7.4 \mathrm{~Hz}, \mathrm{H}), 1.58(\mathrm{~s}, 3 \mathrm{H}), 1.09(\mathrm{~d}$, $J=7.7 \mathrm{~Hz}, 3 \mathrm{H}) ;{ }^{13} \mathrm{C} \mathrm{NMR}\left(100 \mathrm{MHz}, \mathrm{CDCl}_{3}\right) \delta 154.5,150.1$, $144.4,129.1,128.5,128.4,89.1,85.9,81.8,46.1,43.8,25.0$,
13.4; HRMS-ES: $m / z$ calculated for $\mathrm{C}_{15} \mathrm{H}_{15} \mathrm{IO}_{3} \mathrm{Na}[\mathrm{M}+\mathrm{Na}]^{+}$: 392.9964, found 392.9963 .

Ring expansion and the formation of 7,5-fused bicycle (35). A solution of $t$-BuOK (1.0 M solution in $t-\mathrm{BuOH})$ was added to a magnetically stirred solution of the monomesylate $\mathbf{3 4}$ (15 $\mathrm{mg}, 0.0468 \mathrm{mmol})$ in $t-\mathrm{BuOH}$ at $\mathrm{rt}$. The reaction mixture was stirred at $\mathrm{rt}$ for $14 \mathrm{~h}$ and then diluted with water. The product was extracted with ether. The ether extract was washed with water, dried over $\mathrm{MgSO}_{4}$, concentrated and purified by column chromatography to give a colorless solid 35 (8.2 mg, 79\%)

(33): A white solid (mp $\left.150-152^{\circ} \mathrm{C}\right)$; IR (NaCl) 3508, 2985, 2937, 2867, 1454, 1332, 1220, 1173, 1052, $935 \mathrm{~cm}^{-1}$; ${ }^{1} \mathrm{H}$ NMR $\left(400 \mathrm{MHz}, \mathrm{CDCl}_{3}\right) \delta 4.23(\mathrm{~d}, J=2.6 \mathrm{~Hz}, \mathrm{H}), 4.06(\mathrm{~d}, J=2.9 \mathrm{~Hz}$, H), 3.63 (dd, $J=2.2,11.4$ Hz, H), 2.98 (s br, H), 2.87 (s br, H), $2.53(\mathrm{td}, J=2.6,16.5 \mathrm{~Hz}, \mathrm{H}), 2.31$ (d br, $J=11.0 \mathrm{~Hz}, \mathrm{H}), 2.03$ (d br, $J=10 \mathrm{~Hz}, \mathrm{H}), 1.88(\mathrm{td}, J=4.0,16.5 \mathrm{~Hz}, \mathrm{H}), 1.79(\mathrm{~d} \mathrm{br}, J=$ $12.1 \mathrm{~Hz}, \mathrm{H}), 1.75-1.55(\mathrm{~m}, 5 \mathrm{H}), 1.46-1.37(\mathrm{~m}, \mathrm{H}) ;{ }^{13} \mathrm{C} \mathrm{NMR}$ $\left(100 \mathrm{MHz}, \mathrm{CDCl}_{3}\right) \delta 155.1,85.7,81.0,39.0,68.0,38.1,30.9$, 30.0, 22.6, 21.5, 20.6 .

(34): A white solid (mp $153-155^{\circ} \mathrm{C}$ ); IR (NaCl) 3420, 2923, 2854, 1774, 1450, 1355, 1290, $1221 \mathrm{~cm}^{-1}$; ${ }^{1} \mathrm{H}$ NMR (400 MHz, $\left.\mathrm{CDCl}_{3}\right) \delta 4.91(\mathrm{dd}, J=4.7,11.3 \mathrm{~Hz}, \mathrm{H}), 4.31-4.22(\mathrm{~m}, \mathrm{H}), 4.00$ $(\mathrm{q}, J=2.2 \mathrm{~Hz}, \mathrm{H}), 3.73$ (s br, H), 3.07 (s, 3H), 2.42-2.22 (m, 3H), 2.10-2.04 (m, H), 1.82-1.67 (m, 3H), 1.56 (s, 3H), 1.51-1.36 $(\mathrm{m}, 3 \mathrm{H}), 1.33$ (s, 3H), 1.18-1.10 (m, H) ${ }^{13} \mathrm{C}$ NMR (100 MHz, $\left.\mathrm{CDCl}_{3}\right) \delta 109.5,79.0,76.5,72.5,72.4,43.8,39.7,33.9,32.3$, $29.3,27.6,26.7,25.3,21.8$.

(35): A white solid (mp $\left.63-65{ }^{\circ} \mathrm{C}\right)$; IR $(\mathrm{NaCl}) 2929,2857$, 1708, 1464, 1384, 1221, 1149, $1055 \mathrm{~cm}^{-1}$; ${ }^{1} \mathrm{H}$ NMR (400 MHz, $\left.\mathrm{CDCl}_{3}\right) \delta 4.54(\mathrm{t}, J=2.9 \mathrm{~Hz}, \mathrm{H}), 4.31(\mathrm{~d}, J=6.3 \mathrm{~Hz}, \mathrm{H}), 2.82-$ $2.72(\mathrm{~m}, \mathrm{H}), 2.65-2.54$ (m, H), 2.32 (ddd, $J=1.8,10.2,15.4 \mathrm{~Hz}$, H), 2.19 (ddd, $J=3.3,8.4,15.4$ Hz, H), 2.14-2.08 (m, H), 1.86$1.75(\mathrm{~m}, 2 \mathrm{H}), 1.74-1.66(\mathrm{~m}, 2 \mathrm{H}), 1.63-1.55(\mathrm{~m}, \mathrm{H}), 1.35(\mathrm{~s}, 3 \mathrm{H})$, $1.29(\mathrm{~s}, 3 \mathrm{H}), 1.20-1.09(\mathrm{~m}, 2 \mathrm{H}) ;{ }^{13} \mathrm{C} \mathrm{NMR}\left(100 \mathrm{MHz}, \mathrm{CDCl}_{3}\right)$ $\delta$ 108.6, 81.7, 72.3, 54.4, 44.1, 30.1, 27.2, 26.7, 26.3, 26.2, 26.0, 25.4; HRMS (CI+) calcd for $\mathrm{C}_{13} \mathrm{H}_{21} \mathrm{O}_{3}\left[\mathrm{M}^{+}+\mathrm{H}\right] 225.1491$ found 225.1489 .

(36): A white solid (mp $\left.100-101{ }^{\circ} \mathrm{C}\right)$; IR (NaCl) 3457, 2929, 2866, 1775, 1444, 1361, 1257, 1179, $1039 \mathrm{~cm}^{-1} ;{ }^{1} \mathrm{H}$ NMR (400 $\left.\mathrm{MHz}, \mathrm{CDCl}_{3}\right) \delta 4.46(\mathrm{t}, J=3.6 \mathrm{~Hz}, \mathrm{H}), 4.02-3.98(\mathrm{~m}, \mathrm{H}), 3.76(\mathrm{~s}$, H), 3.02 (s br, H), 2.83 (s br, H), 2.24 (td, $J=4.4,14.6 \mathrm{~Hz}, \mathrm{H})$, 2.19-2.13 (m, H), 2.13-2.02 (m, 2H), 2.02-1.78 (m, 6H), 1.78$1.68(\mathrm{~m}, \mathrm{H}), 1.67-1.54(\mathrm{~m}, \mathrm{H}), 1.40-1.30(\mathrm{~m}, \mathrm{H}) ;{ }^{13} \mathrm{C} \mathrm{NMR}(100$ $\left.\mathrm{MHz}_{2} \mathrm{CDCl}_{3}\right) \delta 155.2,89.5,85.5,72.0,66.9,45.5,36.4,31.2$, $30.1,29.1,25.3,23.6$.

(37): A pale yellow oil; IR (NaCl) 2933, 2867, 1699, 1462, 1371, 1207, 1169, $1041 \mathrm{~cm}^{-1} ;{ }^{1} \mathrm{H}$ NMR (400 MHz, $\left.\mathrm{CDCl}_{3}\right) \delta 4.66$ $(\mathrm{t}, J=5.5 \mathrm{~Hz}, \mathrm{H}), 4.49(\mathrm{t}, J=5.1 \mathrm{~Hz}, \mathrm{H}), 3.17(\mathrm{dt}, J=5.5,11.3$ $\mathrm{Hz}, \mathrm{H}), 2.46-2.30$ (m, 2H), 2.25-2.10 (m, H), 1.96 (dt, $J=5.1$, $11.7 \mathrm{~Hz}, \mathrm{H}), 1.88-1.76(\mathrm{~m}, 3 \mathrm{H}), 1.74-1.62(\mathrm{~m}, 2 \mathrm{H}), 1.62-1.52$ $(\mathrm{m}, 2 \mathrm{H}), 1.48(\mathrm{~s}, 3 \mathrm{H}), 1.29(\mathrm{~s}, 3 \mathrm{H}), 1.20-1.01(\mathrm{~m}, \mathrm{H}) ;{ }^{13} \mathrm{C} \mathrm{NMR}$ $\left(100 \mathrm{MHz}, \mathrm{CDCl}_{3}\right) \delta 109.7,83.5,79.8,54.4,49.3,44.0,36.5$, 29.1, 26.7, 25.4, 24.7, 24.4, 22.9; HRMS (CI+) calcd for $\mathrm{C}_{14} \mathrm{H}_{23} \mathrm{O}_{3}\left[\mathrm{M}^{+}+\mathrm{H}\right] 239.1647$ found 239.1648 .

Synthesis of biaryl and structural confirmation (45). To a solution of $\mathrm{rac}-\mathbf{3 8}(109.1 \mathrm{mg}, 0.268 \mathrm{mmol})$ in dichloromethane $(1.0 \mathrm{~mL})$ at $-78^{\circ} \mathrm{C}$ was added dropwise a solution of $\operatorname{IBr}(111$ $\mathrm{mg}, 0.537 \mathrm{mmol})$ in dichloromethane $(1.5 \mathrm{~mL})$. The mixture was 
kept stirred at $-78^{\circ} \mathrm{C}$ for $20 \mathrm{~min}$, then aqueous saturated $\mathrm{Na}_{2} \mathrm{~S}_{2} \mathrm{O}_{3}$ $(4 \mathrm{~mL})$ was added at once. The mixture was allowed to warm to room temperature with stirring. Layers were separated and the aqueous layer was extracted with dichloromethane $(4 \mathrm{~mL} \times$ $3)$. The combined organic layers were dried $\left(\mathrm{MgSO}_{4}\right)$, evaporated, and the residue was purified by silica gel chromatography (EtOAc:Hex $=1: 4$ ) to yield $43.3 \mathrm{mg}$ of a mixture of atropdiastereomer 39/39' (34\%).

(39/39'): ${ }^{1} \mathrm{H}$ NMR (400 MHz, $\left.\mathrm{CDCl}_{3}\right) \delta$ 7.90-7.88 (Ar-H), 7.62-7.59 (Ar-H), 7.56-7.50 (Ar-H), 7.50-7.40 (Ar-H), 7.40-7 .24 (Ar-H), 4.73-4.66 (H, major \& minor), 3.98 (s, 3H, minor), 3.92 (s, 3H, major), 3.42-3.26 (2H, major \& minor), 2.81-2.70 ( $\mathrm{H}$, major \& minor), 2.18-1.95 (m), 1.90-1.70 (m), 1.68-1.52 (m), 1.52-1.25 (m), 1.16-1.02 (m); $\left.{ }^{13} \mathrm{C} \mathrm{NMR} \mathrm{(100} \mathrm{MHz,} \mathrm{CDCl}_{3}\right)$ $\delta$ 154.2/153.8, 145.2/143.4, 131.8, 130.7, 130.5, 129.6, 129.4, $129.1,128.7,128.0,127.4,127.1,126.5,125.3,124.6,124.5$, 124.1, 114.5/113.6, 94.8/93.3, 85.2/84.6, 80.9/79.6, 57.3/56.8, $48.4 / 47.1,44.0 / 43.9,37.7 / 36.7,28.6 / 27.5,24.4 / 24.2,23.1 / 22.9$. (*major/minor)

To a solution of a mixture of 39/39' (48 $\mathrm{mg}, 0.101 \mathrm{mmol}$ ) in THF $(1 \mathrm{~mL})$ was added a solution of $n-\mathrm{Bu}_{4} \mathrm{NOH}(0.11 \mathrm{~mL}$ of $1.0 \mathrm{M}$ in $t$-BuOH, $0.111 \mathrm{mmol}$ ). After stirring $30 \mathrm{~min}$ at $\mathrm{rt}$, water was added and the mixture was extracted with ether. After usual workup and a careful chromatography on a silica gel (EtOAc: Hex $=1: 0$ ), $12.3 \mathrm{mg}$ and $13.8 \mathrm{mg}$ of $\mathbf{4 3} / \mathbf{4 4}$ was separated (total yield, $60 \%)$.

(43 or 44): (lower $R_{f}$ isomer): ${ }^{1} \mathrm{H}$ NMR $\left(400 \mathrm{MHz}, \mathrm{CDCl}_{3}\right) \delta$ $7.89(\mathrm{~d}, J=9.1 \mathrm{~Hz}, \mathrm{H}), 7.82(\mathrm{~d}, J=8.0 \mathrm{~Hz}, \mathrm{H}), 7.74(\mathrm{~d}, J=8.4 \mathrm{~Hz}$, H), 7.47 (t, $J=7.3 \mathrm{~Hz}, \mathrm{H}), 7.37$ (t, $J=7.4 \mathrm{~Hz}, \mathrm{H}), 7.31$ (d, $J=9.2$ $\mathrm{Hz}, \mathrm{H}), 6.52$ (d, $J=9.2 \mathrm{~Hz}, \mathrm{H}), 5.65$ (dd, $J=1.4,9.9 \mathrm{~Hz}, \mathrm{H}), 3.98$ (s, 3H), 2.43 (dd, $J=3.3,12.4 \mathrm{~Hz}, \mathrm{H}), 1.96(\mathrm{~d} \mathrm{br}, J=12.5 \mathrm{~Hz}, \mathrm{H})$, 1.88 (d br, $J=13.2 \mathrm{~Hz}, \mathrm{H}), 1.72$ (d br, $J=11.3 \mathrm{~Hz}, \mathrm{H}), 1.61-1.20$ $(\mathrm{m}, 5 \mathrm{H}) ;{ }^{13} \mathrm{C}$ NMR $\left(100 \mathrm{MHz}, \mathrm{CDCl}_{3}\right) \delta 154.3,144.6,134.6$, 134.1, 131.0, 130.4, 129.5, 128.8, 127.9, 127.3, 126.0, 124.5, $113.6,94.5,70.5,57.3,53.4,37.8,29.2,24.3,23.5$.

(43 or 44): (higher $R_{f}$ isomer): ${ }^{1} \mathrm{H}$ NMR $\left(400 \mathrm{MHz}, \mathrm{CDCl}_{3}\right)$ $\delta 8.00(\mathrm{~d}, J=8.4 \mathrm{~Hz}, \mathrm{H}), 7.87(\mathrm{~d}, J=8.8 \mathrm{~Hz}, \mathrm{H}), 7.80(\mathrm{~d}, J=8.4$ $\mathrm{Hz}, \mathrm{H}), 7.46$ (t, J=7.7 Hz, H), 7.35 (t, J=7.0 Hz, H), 7.30 (d, $J=9.1 \mathrm{~Hz}, \mathrm{H}), 6.59$ (d, $J=9.5 \mathrm{~Hz}, \mathrm{H}), 5.60$ (d, $J=9.5 \mathrm{~Hz}, \mathrm{H})$, $3.95(\mathrm{~s}, 3 \mathrm{H}), 2.56(\mathrm{dd}, J=4.0,12.1 \mathrm{~Hz}, \mathrm{H}), 2.00-1.81(\mathrm{~m}, 3 \mathrm{H})$, $1.72(\mathrm{~d} \mathrm{br}, J=13.2 \mathrm{~Hz}, \mathrm{H}), 1.61 .52-1.40(\mathrm{~m}, 3 \mathrm{H}), 1.30-1.18$ (m, $\mathrm{H}) ;{ }^{13} \mathrm{C}$ NMR $\left(100 \mathrm{MHz}, \mathrm{CDCl}_{3}\right) \delta 153.2,146.3,136.7,133.7$, 131.6, 130.4, 129.6, 128.7, 127.5, 126.5, 125.2, 124.3, 113.8, 93.7, 71.6, 56.9, 53.0, 39.1, 28.6, 24.4, 24.2.

To a solution of 43 (7.2 mg, $0.0166 \mathrm{mmol}$, lower spot) in toluene was added $\mathrm{TsOH} \cdot \mathrm{H}_{2} \mathrm{O}(1.5 \mathrm{mg}, 0.5$ equiv. $)$ and the mixture was heated at $80^{\circ} \mathrm{C}$ for $30 \mathrm{~min}$. After simple filtration through a silica pad and evaporatio of volatile, $r a c-45$ was obtained in $6.5 \mathrm{mg}(97 \%)$ yield. The upper $R_{f}$ isomer was similarly treated with $\mathrm{TsOH}_{\mathrm{H}} \mathrm{O}$ to provide a compound having identical ${ }^{1} \mathrm{H}$ and ${ }^{13} \mathrm{C}$ spectra.

(45): ${ }^{1} \mathrm{H} \mathrm{NMR}\left(400 \mathrm{MHz}, \mathrm{CDCl}_{3}\right) \delta 7.93(\mathrm{~d}, J=9.2 \mathrm{~Hz}, \mathrm{H})$, 7.86-7.82 (m, H), $7.74(\mathrm{~d}, J=8.5 \mathrm{~Hz}, \mathrm{H}), 7.37$ (d, $J=8.8 \mathrm{~Hz}, \mathrm{H})$, 7.36-7.30 (m, 2H), 7.13-7.09 (m, H), 6.88 (d, $J=8.0 \mathrm{~Hz}, \mathrm{H}), 3.90$ $(\mathrm{s}, 3 \mathrm{H}), 2.82(\mathrm{t}, J=6.2 \mathrm{~Hz}, 2 \mathrm{H}), 2.37-2.24(\mathrm{~m}, 2 \mathrm{H}), 2.16-2.05(\mathrm{~m}$, 2H), 1.78-1.67 (m, 2H), 1.66-1.50 (m, 2H); ${ }^{13} \mathrm{C} \mathrm{NMR} \mathrm{(100} \mathrm{MHz,}$ $\left.\mathrm{CDCl}_{3}\right) \delta 153.9,141.5,139.2,138.1,136.2,132.9,131.1,130.1$, 129.7, 128.7, 127.5, 127.4, 124.7, 124.3, 114.3, 99.4, 57.2, 30.3, $29.0,23.8,23.1$.

Acknowledgments. This work was supported by the research fund of Hanyang University (HY-2007-I). YL and CL thank BK21 program for financial support.

\section{References}

1. (a) Tietze, L. F. Chem. Rev. 1996, 96, 115. (b) Malacria, M. Chem. Rev. 1996, 96, 289. (c) Burke, M. D.; Schreiber, S. L. Angew. Chem. Int. Ed. 2004, 43, 46.

2. For recent reviews, see: (a) Jiménez-Núnez, E.; Echavarren, A. M. Chem. Rev. 2008, 108, 3326. (b) Gorin, D. J.; Sherry, B. D.; Toste, F. D. Chem. Rev. 2008, 108, 3351. (c) Michelet, V.; Toullec, P. Y.; Genêt, J. P. Angew. Chem. Int. Ed. 2008, 47, 4268. (d) Hashmi, A. S. K. Chem. Rev. 2007, 107, 3180. (e) Fürstner, A.; Davies, P. W. Angew. Chem. Int. Ed. 2007, 46, 3410.

3. (a) Lim, C.; Kang, J.-E.; Lee, J.-E.; Shin, S. Org. Lett. 2007, 9, 3539. (b) Kang, J.-E.; Lee, E. S.; Park, S. I.; Shin, S. Tetrahedron Lett. 2005, 46, 7431. (c) Kang, J.-E.; Shin, S. Synlett 2006, 717. (d) Buzas, A.; Gagosz, F. Synlett 2006, 2727. (e) Lee, E.-S.; Yeom, H.-S.; Hwang, J.-H.; Shin, S. Eur. J. Org. Chem. 2007, 3503. (f) Hashmi, A. S. K.; Salathé, R.; Frey, W. Synlett 2007, 1763. (g) Istrate, F.; Buzas, A.; Dias Jurberg, I.; Odabachian, Y.; Gagosz, F. Org. Lett. 2008, 10, 925. (h) Buzas, A.; Istrate, F.; Le Goff, X. F.; Odabachian, Y.; Gagosz, F. J. Organomet. Chem. 2009, 694, 515. (i) Buzas, A.; Istrate, F. M.; Gagosz, F. Tetrahedron 2009, 65, 1889. (j) Cheong, J. Y.; Bae, H. J.; Baskar, B.; Thangadurai, D.; Kim, M.-J.; Rhee, Y. H. Bull. Korean Chem. Soc. 2009, 30, 1239.

4. (a) Lim, C.; Rao, M. S.; Shin, S. Synlett in press (doi \#: S11009ST). For a recent review comparing metal-catalyzed and iodoniumtriggered reactions, see: (b) Yamamoto, Y.; Gridnev, I. D.; Patil, N. T.; Jin, T. Chem. Commun. 2009, 5075. For a prototypical iodocarbonatation of olefin, see: (d) Duan, J. J.-W.; Smith, A. B. J. Org. Chem. 1993, 58, 3703 .

5. (a) Trost, B. M.; Machacek, M. R.; Tsui, H. C. J. Am. Chem. Soc. 2005, 127, 7014. (b) Smith, A. B.; Kim, D.-S.; Xian, M. Org. Lett. 2007, 9, 3307. (c) Trost, B. M.; Chan, D. M. T.; Nanninga, T. N. Org. Synth. 1984, 62, 58.

6. (a) Okazaki, T.; Laali, K. K. J. Org. Chem. 2005, 70, 9139. (b) Okazaki, T.; Laali, K. K. J. Org. Chem. 2006, 71, 9643. (c) Strozier, R. W.; Caramella, P.; Houk, K. N. J. Am. Chem. Soc. 1979, 79, 1340.

7. (a) Hayashi, T. Acc. Chem. Res. 2000, 33, 354. (b) Hayashi, T.; Kawatsura, M.; Uozumi, Y. J. Am. Chem. Soc. 1998, 120, 1681. (c) Hayashi, T. J. Organomet. Chem. 1999, 576, 195. (d) Uozumi, Y.; Kitayama, K.; Hayashi, T. Tetrahedron: Asymmetry 1993, 4, 2419. 